\title{
Neurological and Epidemiological Aspects of a BoHV-5 Meningoencephalitis Outbreak
}

\author{
Michele Lunardi ${ }^{1}$, Marlise Pompeo Claus ${ }^{1}$, Júlio Augusto Naylor Lisbôa ${ }^{2}$, Alexandre \\ Mendes Amude ${ }^{1,3}$, Selwyn Arlington Headley, Alice Fernandes Alfieri ${ }^{1}$ and Amauri \\ Alcindo Alfieri ${ }^{1^{*}}$ \\ ${ }^{1}$ Laboratório de Virologia Animal; Departamento de Medicina Veterinária Preventiva; Universidade Estadual de \\ Londrina; Londrina - PR - Brasil. ${ }^{2}$ Departamento de Clinicas Veterinárias; Universidade Estadual de Londrina; \\ Londrina - PR - Brasil. ${ }^{3}$ Departamento de Clinicas Veterinárias; Universidade de Cuiabá; Cuiabá - MG - Brasil. \\ ${ }^{4}$ Department of Basic Veterinary Sciences, School of Veterinary Medicine, St. Matthew's University, Grand \\ Cayman, Cayman Islands, British West Indies
}

\begin{abstract}
Bovine herpesvirus 5 is a DNA virus that has been associated with meningoencephalitis in young cattle. While its clinical diagnosis is obscured by other major diseases that also produce similar neurological disease in cattle, the use of conventional virological techniques is hampered by the establishment of a lifelong latent infection in the host and the difficulty in differentiating BoHV-1 and BoHV-5. The aim of the current report is to describe the clinical and epidemiological aspects observed in a natural outbreak of BoHV-5 meningoencephalitis in a dairy cattle herd from Brazil. In the outbreak, the affected animals consisted of nine calves, which presented three possible forms of the neurological disease, subjectively classified as peracute, acute, and subacute/chronic. In contrast to conventional herpetic meningoencephalitis, characterized mainly by progressive multifocal brain dysfunctions, BoHV-5 infection resulted in focal non-progressive caudal brainstem dysfunction (pontomedullary syndrome) in an animal presented with subacute/chronic BoHV-5 meningoencephalitis. The evaluation of CNS tissue of affected calves through both histological examination and multiplex-PCR was able to confirm BoHV-5 infection. Additionally, the analysis of CSF samples through PCR allowed ante-mortem BoHV-5 diagnosis during the outbreak, which enabled the implementation of several measures of control for the disease.
\end{abstract}

Key words: cattle, central nervous system, bovine herpesvirus 5, multiplex-PCR

\section{INTRODUCTION}

Bovine herpesvirus 5 (BoHV-5) is an enveloped DNA virus that belongs to Herpesviridae family, Alphaherpesvirinae subfamily and Varicellovirus genus (Roizman et al., 1992). Despite genetic and antigenic similarities, BoHV-1 and BoHV-5 differ in their neurotropism. While BoHV-1 is the etiological agent of infectious bovine rhinotracheitis (IBR), and rarely causes neurological signs, BoHV-5 has been classically considered the causal agent of meningoencephalitis in young cattle of specific geographical areas, mainly Brazil, Argentina, the U.S. and Australia (Johnston et al., 1962; Carrillo

*Author for correspondence: alfieri@uel.br 
et al., 1983; D’Offay et al., 1993; Salvador et al., 1998; Colodel et al., 2002).

In Brazil, the occurrence of the disease has been reported in several geographic regions, with cases and/or outbreaks reported in the northern (RietCorrea et al., 2006), central western (Salvador et al., 1998; Colodel et al., 2002), southeastern (Salvador et al., 1998; Gomes et al., 2002), and southern regions (Claus et al., 2007; Rissi et al., 2008).

The neurological signs observed in BoHV-5 infections are often multifocal deficits and comprise mainly cerebral and brainstem dysfunctions. Opisthotonus, focal to generalized seizures, central blindness, head pressing, inappropriate consciousness content (behavioral changes), and teeth grinding are examples of cerebral dysfunction often reported in BoHV-5 infection, while alterations of consciousness level (depression/somnolence, stupor, and coma), and motor dysfunction (tetraparesis) associated with cranial nerve deficits such as nystagmus, head tilt, strabismus, facial paralysis, and dysphagia/ptyalism reflect brainstem dysfunction. Vestibular or cerebral circling may also be observed, as well as incoordination and trembling. Spastic recumbency may be verified in animals with severe motor dysfunction due to upper motor neuron damage. Anorexia, nasal and ocular discharge may also be verified associated with the neurological disease. Unfortunately, the natural course of the disease usually leads to death, despite medical treatment (Salvador et al., 1998; Sanches et al., 2000; Colodel et al., 2002; Perez et al., 2002).

Other major diseases, such as rabies, bacterial meningoencephalitis, cerebral babesiosis, and polioencephalomalacia (PEM), may also lead to neurological disease in cattle (Sanches et al., 2000), mimicking the nervous presentation of BoHV-5 infection, since the neurological signs depend on the neuroanatomical structure damaged and not on the etiological agent involved. Therefore, a precise and practical clinical diagnosis of BoHV-5 meningoencephalitis cannot be performed only based on the data from neurological and clinical examination; thus, in order to diagnose BoHV-5 meningoencephalitis, laboratory techniques are essential to detect viral infection.

Due to the ability of BoHV to establish a lifelong latent infection in the host and the difficulty in differentiating BoHV-1 and BoHV-5, which share antigenic characteristics and cause cross reactions in serological methods, the use of classical virological techniques, such as virus neutralization and virus isolation in cell culture, have limited value to differentiate both viral types. Therefore, the technique employed for the diagnosis of herpetic meningoencephalitis should successfully differentiate BoHV-5 from BoHV-1. Thus, isolated viruses and samples collected from affected animals must be analyzed using sensitive and reliable molecular techniques, such as multiplex-polymerase chain reaction (PCR), designed to detect specific and distinct regions of the BoHV DNA not shared by both BoHV-1 and BoHV-5 (Ashbaugh et al., 1997; Claus et al., 2005). Accordingly, the aim of this paper is to report a herpetic meningoencephalitis outbreak in a cattle herd in the state of Parana in Brazil due to BoHV-5 infection and in which the accurate etiological diagnosis was carried out by multiplexPCR. In addition, the neuroclinical, neuropathological, and epidemiological aspects observed in this natural BoHV-5 outbreak are discussed and may contribute to the knowledge, understanding, and clinical characterization of the different neurological courses of BoHV-5 meningoencephalitis under natural conditions of the disease.

\section{MATERIALS AND METHODS}

\section{Cattle herd}

The BoHV-5 outbreak herein described occurred during the winter. The affected animals belonged to a dairy herd of Brown Swiss cattle from Apucarana city, latitude $-23^{\circ} 33^{\prime} \quad 03^{\prime \prime}$ and longitude $51^{\circ} 27^{\prime} 39^{\prime \prime}$, Northern Parana, Brazil.

Cattle were raised in an intensive system; however, the management observed in the farm was inadequate in several aspects, such as environmental upkeep, sanitary practices, and nutritional sufficiency. Animals were not vaccinated against BoHV-1 before the occurrence of the disease.

Affected animals consisted of nine calves in which clinical signs were characterized by neurological disturbances. These calves were followed and submitted to regular clinical evaluation. 


\section{Virus neutralization technique (VN)}

Serologic evaluation for BoHV antibodies detection was performed in all animals belonging to the following categories: i) suckling calves aging up to four months ( $n=64)$; ii) weaned calves ranging in age from 4 to 13 months $(n=85)$; and iii) lactating cows $(n=90)$.

Titulation for BoHV-1 antibody detection in serum samples was obtained using the $\mathrm{VN}$ technique, which employed MDBK (Madin Darby bovine kidney) cells and the Los Angeles strain of BoHV1 at 100 TCID 50\% (Ferreira et al., 2005). Serum samples, whose titers $(\geq 8)$ were able to inhibit $100 \%$ of the cytopathic effect, were considered positive.

\section{Histopathology}

After natural death or euthanasia, seven out of nine affected calves were submitted to necropsy, and representative samples from the brain [cerebrum $(n=7)$, cerebellum $(n=7)$, and medulla oblongata $(n=3)$ ] were collected, fixed in $10 \%$ buffered neutral formalin, embedded in histological paraffin, sectioned at $5 \mu \mathrm{m}$, and stained with hematoxylin and eosin (HE), following routine procedures. Brain coronal sections were evaluated in order to detect neuroparenchymal lesions compatible with BoHV-5 infection as previously described (Summers et al., 1995).

\section{Multiplex Polymerase chain reaction (PCR)}

In order to diagnose BoHV meningoencephalitis in the calves that presented with neurological dysfunctions, cerebrospinal fluid (CSF) samples collected from five affected animals, and brain fragments of necropsied calves $(n=7)$ were tested for the presence of both BoHV-1 and BoHV-5 DNA using a multiplex-PCR designed to detect the glycoprotein $\mathrm{C}$ gene. For DNA extraction from fresh brain fragments, a combination of the phenol/chloroform/isoamyl alcohol and silica/guanidine isothiocyanate methods was carried out according to Alfieri et al. (2006). CSF samples were submitted to the PCR assay without prior DNA extraction.

Multiplex-PCR was carried out using the primers designated as $\mathrm{B} 1$, specific for BoHV-1 (5'-CAA CCG AGA CGG AAA GCT CC-3', nt 185-204), B5, specific for BoHV-5 (5'-CGG ACG AGA CGC CCT TGG-3', nt 322-339), and a consensus primer designated Bcon [5'-AGT GCA CGT ACA GCG GCT CG-3', nt 519-538 (BoHV-1) and nt
461-480 (BoHV-5)]. Reaction was performed using $5 \mu \mathrm{L}$ of extracted DNA and $45 \mu \mathrm{L}$ of PCRmix consisting of 0.4 pmol of each primer (B1, B5 and Bcon); $1.6 \mathrm{mM}$ dNTP (Invitrogen, Life Technologies, USA); 2.5 units of Platinum Taq DNA Polymerase (Invitrogen, Life Technologies, USA); $1 \times$ PCR buffer $(20 \mathrm{mM}$ Tris- $\mathrm{HCl} \mathrm{pH} 8.4$; $50 \mathrm{mM} \mathrm{KCl}$ ); $1.5 \mathrm{mM} \mathrm{MgCl}_{2} ; 8 \%$ dimethyl sulfoxide (Sigma, USA), and ultrapure sterile water to a final volume of $45 \mu \mathrm{L}$. Amplification was performed in a thermocycler (PTC 200, MJ Research Co., USA) with the following cycling profile: an initial step of $3 \mathrm{~min}$ at $94{ }^{\circ} \mathrm{C}$, followed by 40 cycles of $1 \mathrm{~min}$ at $94{ }^{\circ} \mathrm{C}, 1 \mathrm{~min}$ at $58{ }^{\circ} \mathrm{C}, 1$ min at $72{ }^{\circ} \mathrm{C}$, and a final extension step of $7 \mathrm{~min}$ at $72{ }^{\circ} \mathrm{C}$ (Claus et al., 2005).

PCR products were analyzed by electrophoresis on $2 \%$ agarose gel in TBE buffer, $\mathrm{pH} 8.4(89 \mathrm{mM}$ Tris; $89 \mathrm{mM}$ boric acid; $2 \mathrm{mM}$ EDTA), at constant voltage $(90 \mathrm{~V})$ for approximately $45 \mathrm{~min}$, stained with ethidium bromide $(0.5 \mu \mathrm{g} / \mathrm{mL})$ and visualized under UV light.

\section{RESULTS AND DISCUSSION}

The multiplex-PCR assay employed in this study detected the presence of BoHV-5 as the single casual agent in all affected calves evaluated $(n=7)$. Whereas the 354 bp BoHV-1 specific product was not amplified in any sample tested, the specific amplicon for BoHV-5, with 159 bp size, was detected in six samples of cerebrum $(6 / 7)$, three samples of cerebellum (3/7), two samples of medulla oblongata (2/3), and two samples of CSF $(2 / 5)$. The non-simultaneous detection of the BoHV-5 in all brain fragments evaluated can be explained by the irregular distribution of the virus in the brain of affected calves (Isernhagen, 2005). The importance of this report lies in the fact that the BoHV type involved in the neurological outbreak was accurately identified.

Even though both BoHV-1 and BoHV-5 may lead to neurological dysfunctions in cattle herds through naturally occurring disease, few reports have demonstrated the presence of BoHV-1 in brain of cattle affected by herpetic meningoencephalitis (Roels et al., 2000; Penny et al., 2002). In contrast, BoHV-5 is frequently associated with neurological disease in young calves. In the presented herpetic neurological outbreak, BoHV-1 was excluded as the causal 
agent of the nervous disease, since all brain samples from affected calves were tested by a multiplex-PCR designed for detection of both BoHV-1 and BoHV-5 DNA. The differential diagnosis for these two viruses is extremely important, since both viruses may lead to identical neurological presentation, which may make impossible the differentiation of nervous disease from both BoHV-1 and BoHV-5 only by neuroclinical parameters. In addition, BoHV-5 may also mimic the non-nervous disease typically reported with BoHV-1 infection; BoHV-5 has been detected from specimens collected of naturally occurring respiratory disease and from aborted fetuses. Experimentally, respiratory disease has also been reproduced in BoHV5-inoculated calves (Carrillo et al., 1983; Belknap et al., 1994; Vogel et al., 2004).

The BoHV-5 outbreak here described was characterized only by the neurological signs of BoHV. Although BoHV-5 was probably circulating throughout the herd, the neurological disease occurred only in young cattle, aging from 30 days to seven months. Nine affected calves were clinically evaluated, 6 of them being kept at the Veterinary Teaching Hospital until their natural death or euthanasia.

The medical follow-up at the Veterinary Hospital allowed a close monitoring of their neuroclinical evolution. The progression of the nervous disease in affected calves allowed the recognition of three different forms, subjectively classified as peracute, acute, and subacute/chronic. While peracute and acute BoHV-5 forms were characterized by progressive neurological dysfunctions, the subacute/chronic form was marked by a nonprogressive neurological course. Calves experiencing peracute BoHV-5 form $(n=3)$ experienced rapid progressive worsening leading to death up to 48 hours from the onset of clinical signs. Cerebral dysfunction characterized by generalized seizures was the most consistent neurological presentation of this peracute form; however, brainstem deficits also could be recognized. Acute BoHV-5 form led natural death in calves $(n=3)$ after 3 to 7 days of progressive signs, and neurological deficits were characterized mainly by cerebral deficits. In contrast to the peracute and acute forms, the subacute/chronic form of BoHV-5 disease was characterized by mild non-progressive nervous disease with neurological presentations varying from focal to multifocal nervous system dysfunction; all animals that presented with this subacute/chronic form $(n=3)$ were submitted to euthanasia within 7 to 21 days of clinical course.

In this outbreak, the variation in the duration of the BoHV-5 nervous disease ranged from 18 hours to 21 days. These results were slightly higher than those related in other studies, which have ranged from 1 to 15 days (Salvador et al., 1998; Colodel et al., 2002; Elias et al., 2004; Riet-Correa et al., 2006; Rissi et al., 2006). Additionally, the association of each of the different BoHV-5 nervous forms of disease with a specific age was not verified in this outbreak (Table 1).

Table 1- Clinical aspects related to each of the forms of the disease.

\begin{tabular}{cccccc}
\hline \multirow{2}{*}{ Form of disease } & \multirow{2}{*}{ Age } & \multirow{2}{*}{ Sex } & \multicolumn{2}{c}{ Clinical evolution } & \multirow{2}{*}{ Death } \\
\cline { 4 - 5 } & & Period & Type & natural \\
peracute & $38 \mathrm{~d}$ & male & $36 \mathrm{~h}$ & progressive & natural \\
peracute & $40 \mathrm{~d}$ & male & $18 \mathrm{~h}$ & progressive & natural \\
peracute & $2 \mathrm{~m}$ & male & $24 \mathrm{~h}$ & progressive & natural \\
acute & $30 \mathrm{~d}$ & male & $3 \mathrm{~d}$ & progressive & natural \\
acute & $7 \mathrm{~m}$ & male & $7 \mathrm{~d}$ & progressive & natural \\
acute & $4 \mathrm{~m}$ & male & $7 \mathrm{~d}$ & progressive & euthanasia \\
subacute/chronic & $4 \mathrm{~m}$ & male & $16 \mathrm{~d}$ & stationary & euthanasia \\
subacute/chronic & $40 \mathrm{~d}$ & female & $21 \mathrm{~d}$ & stationary & euthanasia \\
subacute/chronic & $4,5 \mathrm{~m}$ & male & $>7 \mathrm{~d}$ & stationary \\
\hline
\end{tabular}

Concomitant cerebral and brainstem dysfunctions manifested, respectively, by cortical signs and cranial nerve deficits could be verified in the peracute form of the disease; cortical signs were characterized by generalized to focal seizures, central blindness (amaurosis), and opisthotonus (descerebration posture). Generalized seizure was manifested as the twitching of all skeletal muscles (tonic-clonic movements) associated with loss of consciousness, while focal seizures were manifested as the twitching of facial muscles. Brainstem dysfunctions in the peracute disease 
were characterized by depression/somnolence (ascending reticular activating system impairment), tongue paresis (XII cranial nerve deficit), dysphagia with salivation (IX, X, or XII cranial nerve deficit), nystagmus (VIII cranial nerve deficit), and mydriasis (III cranial nerve deficit). Recumbency due to long motor tract fiber damage (extrapyramidal motor system) was also verified in the peracute form.

Neurological deficits from the acute form of BoHV-5 disease were characterized mainly by cerebral deficits such as focal seizures (twitching of facial muscles), central blindness (amaurosis), and compulsive circling. Depression/somnolence observed in the acute form might, hypothetically, be due to both: i) bilateral diffuse cortical damage; or ii) brainstem damage with ascending reticular activating system impairment; however, the absence of concomitant cranial nerve deficits suggests the first hypothesis as the most acceptable. Recumbency and intermittent generalized seizure were presented late in the acute form.

Neurological signs observed in the subacute/chronic BoHV-5 form varied among affected calves; in one out of three animals, the neurological presentation was characterized by pontomedullary syndrome (focal caudal brainstem dysfunction - pons and medulla oblongata) with signs of long tract motor dysfunction and multiple cranial nerve deficits such as impairment of the IX/X cranial nerve (dysphagia) and impairment of the VII cranial nerve (bilateral ear and eyelid drop - ear and eyelid paralysis). In the other two animals, mild neurological dysfunctions were manifested by multifocal nervous signs characterized by cortical (unilateral amaurosis, and repetitive "chewing gum fits" - focal seizure), and brainstem [depression/somnolence, unilateral ear drop (VII cranial nerve deficit), tongue paresis (XII cranial nerve deficit), tetraparesis and reluctance to walk (extrapyramidal motor system)] deficits.

The peracute and acute progressive fatal forms of BoHV-5 meningoencephalitis have been the typical courses of the naturally occurring disease. The occurrence of BoHV-5 meningoencephalitis as a mild neurological disease or in a non-fatal form, as the subacute/chronic form herein described, has also been reported in both natural and experimental infection. However, the subacute/chronic case herein presented in which the BoHV-5 infection was manifested as focal caudal brainstem dysfunction (pontomedullary syndrome) could be considered unusual, since subacute/chronic BoHV-5 disease has been typically characterized by diffuse neurological disease with multifocal brain dysfunctions. The remaining neurological deficits observed in this outbreak were similar to those previously described in both naturally and experimentally induced infections (Cascio et al., 1999; Colodel et al., 2002; Perez et al., 2002; Elias et al., 2004; Rissi et al., 2006; 2008; Spilki et al., 2006).

Histological examination of the brain sections from seven affected calves revealed nervous lesions compatible with viral encephalitis, such as the presence of mild to moderate non-suppurative meningoencephalitis (perivascular cuffing of mononuclear inflammatory cells) (Fig. 1A) in both white and gray matters of the cerebrum and cerebellum. Additionally, vasculitis, astrogliosis and astrocytosis, and discrete areas of malacia characterized by neuroparenchymal necrosis with Gitter cell infiltration were observed in the gray matter of the cerebrum. Malacia of the cerebral cortex has been a typical neuropathological finding of herpesvirus encephalitis (Summers et al., 1995). Eosinophilic intranuclear inclusion bodies, typical of herpesvirus, could also be observed in astrocytic-like cells (Fig. 1B). Similar neuroparenchymal findings have been demonstrated in different studies involving naturally occurring BoHV-5 nervous disease (Salvador et al., 1998; Colodel et al., 2002; Perez et al., 2003; Elias et al., 2004).

Different laboratorial techniques have been applied to brain samples for the definitive postmortem diagnosis of BoHV-5 meningoencephalitis, such as histopathology/immunohistochemistry (Rissi et al., 2008), virus isolation in cell culture, and BoHV-5 DNA detection by PCR assay (Vogel et al., 2003; Claus et al., 2007). However, the possibility of carrying out a specific ante-mortem diagnosis of BoHV-5 meningoencephalitis outbreak is extremely important, since this procedure may allow differential diagnosis from among other important causes of encephalopathy in cattle, such as rabies, and may also lead to the early implementation of several measures for control of the disease, as an immediate attempt to reduce the number of affected animals. Accordingly, the BoHV-5 DNA detection by PCR in CSF samples from affected cattle during a neurological disease outbreak may represent a reliable way to obtain a 
specific ante-mortem diagnosis of BoHV-5 infection. In the presented neurological outbreak, BoHV-5 could be detected in two out of five CSF samples tested. Although the sensitivity of the CSF was not very high, the ante-mortem diagnosis of BoHV-5 meningoencephalitis was successfully performed in this outbreak. Different variables may influence the sensitivity of viral detection in
CSF as follows: i) pathway of virus entry into nervous system; ii) evolution of the nervous disease; iii) neurobiology of the infection; iv) the degree and type of virus assembly; v) the presence or absence of nervous cell cytolysis; and vi) the type, degree of inflammation, extension, and neuroanatomical distribution of the neuroparenchymal lesions (Amude, 2008).

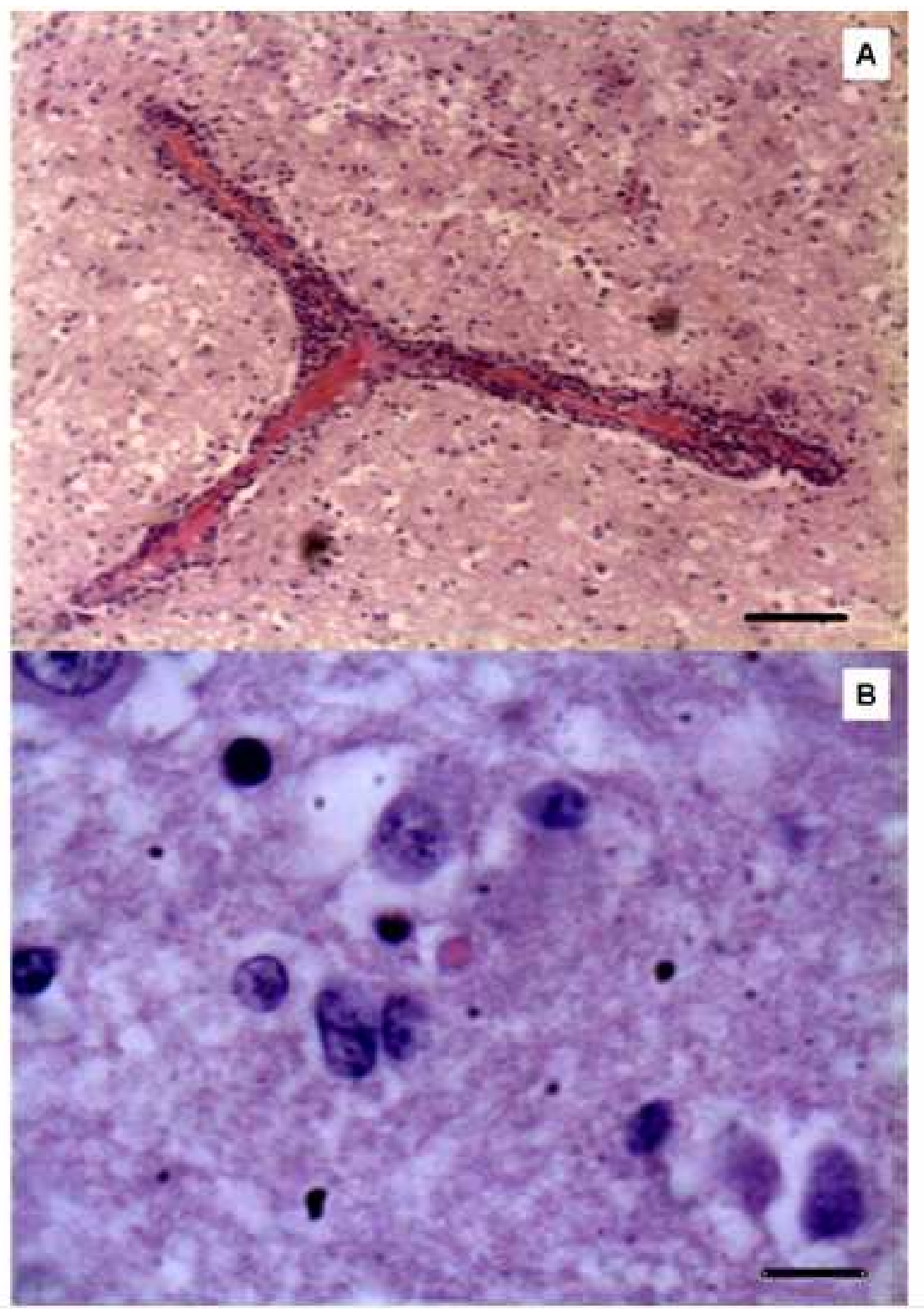

Figure 1 - A) Endothelial reactivity with nuclear swelling and mild perivascular cuffing of mononuclear cells (HE, Obj 40x). B) Observed distinct intranuclear inclusion body in astrocytic-like cell (HE, Obj. 100x). 
Due to the intense cross reaction observed between BoHV-1 and BoHV-5 in serological methods, the VN technique here employed was performed with a BoHV-1 strain. From the 239 serum samples evaluated for the presence of antibodies against BoHV, $41.88 \%$ of samples (100/239) tested negative (titers $\leq 4)$, while $58.12 \%$ (139/239) tested positive (titers $\geq 8$ ). The remarkable variation in titers for BoHV antibodies observed in this herd as well as the high rate $(22.18 \%)$ of animals tested positive with titers $\geq 64$ demonstrated the presence of the virus in the herd. Serum samples collected from five affected calves and their respective dams were also evaluated by VN technique. Affected calves tested negative or presented low serological titers for BoHV antibodies, while their dams presented higher serological titers. The serological investigation suggested recent BoHV infection throughout the herd; nevertheless, multiplex-PCR confirmed BoHV-5 rather than BoHV-1 as the etiological agent of the nervous disease.

Since the serological evaluation performed in both calves aging up to 13 months and their respective dams indicated different rates of positivity for BoHV antibodies in each of these two categories (calves and dams), we believe that a possible failure in the transference of passive immunity might have contributed to the occurrence of viral disease in the youngest calves (Fig. 2). Additionally, as the management observed in this farm was inadequate, especially that involving nutritional aspects for young calves, we believe that this failure might be a consequence of an inadequate intake of colostrum in the first hours of life, which has been widely recognized.

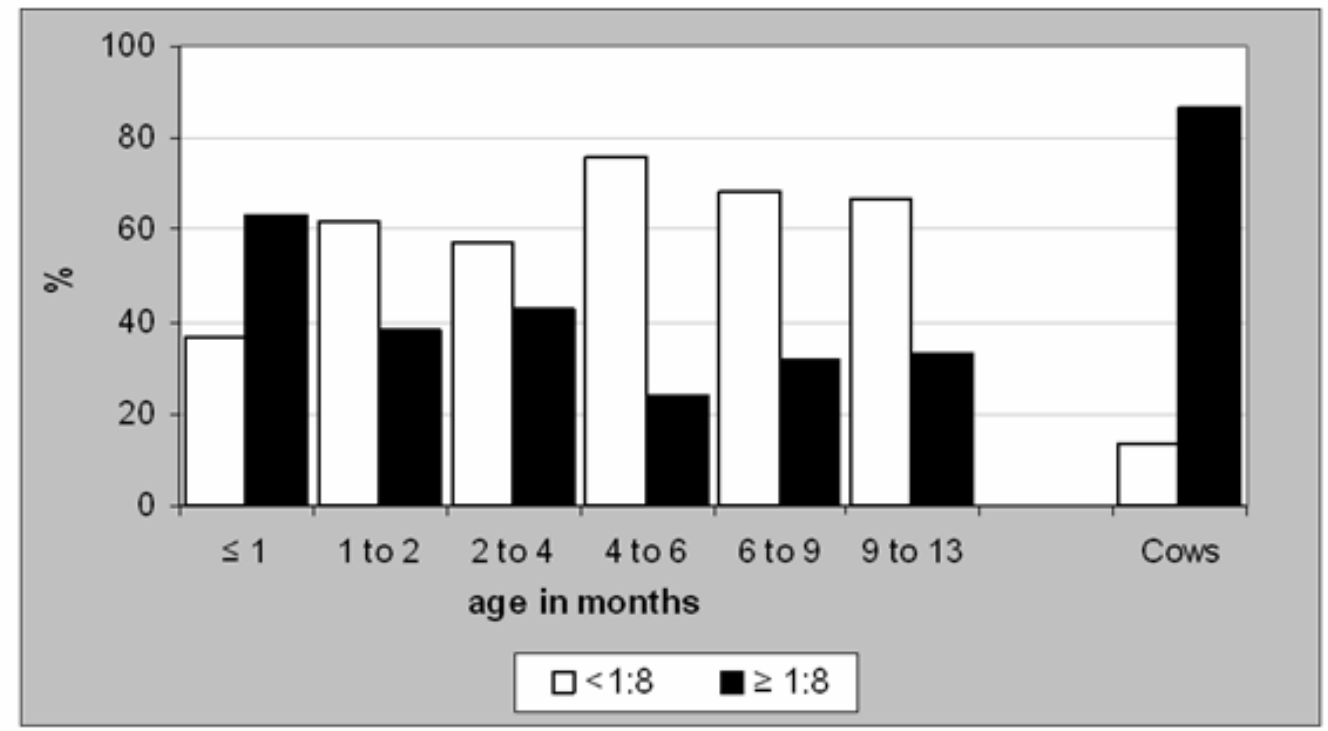

Figure 2 - Serological evaluation of calves and their dams. While the majority of cows tested positive for BoHV antibodies, most of calves in the 0 day to 13 months age range tested negative.

In this outbreak, several measures were implemented as an attempt to control the spread of the infection in the most susceptible animal category, represented by young calves. These measures consisted of isolation of calves presenting neurological signs, rigorous disinfection of all facilities where affected animals were kept, and the use of a BoHV-1-based vaccine in non-affected young calves. Because of
BoHV-1 and BoHV-5 share similar genetic and antigenic characteristics, and because a BoHV5-based vaccine is not commercially available, vaccination using BoHV-1 antigens can be used to reduce losses caused by BoHV-5 during outbreaks of neurological disease (Salvador et al., 1998; Cascio et al., 1999; Del Médico et al., 2006).

In conclusion, the association of the following factors likely determined the occurrence of this 
outbreak: i) maintenance of animals of diverse ages in the same facility; ii) inadequate corporal score for young calves; iii) inappropriate disinfection of environment; iv) the nonvaccination of the herd against BoHV-1; v) the presence of the BoHV-5 in the herd; vi) and a nonprovision of care to ensure adequate intake of colostrum for young calves.

\section{ACKNOWLEDGEMENTS}

The financial resources for the conduction of this study were supported by the project BioAgroPar financed by FINEP, SETI/PR, and Fundação Araucária/PR; and by CNPq/Brazil.

Part of the research activities of this study was carried out in the Agricultural Research Support Laboratory (Laboratório de Apoio à Pesquisa Agropecuária - LAPA) / PROPPG / UEL.

Alfieri, A.F. and Alfieri, A.A. are recipients of CNPq fellowships.

\section{RESUMO}

O herpesvírus bovino 5 é um vírus DNA que tem sido associado a casos de meningoencefalite em bovinos jovens. Enquanto o diagnóstico clínico da doença é dificultado pelo fato de outras enfermidades importantes também determinarem quadro neurológico em bovinos, a utilização de técnicas virológicas convencionais no diagnóstico laboratorial tem sido inviabilizada pela latência viral que ocorre no hospedeiro e pela dificuldade em se diferenciar o BoHV-1 do BoHV-5. O objetivo deste relato é o de descrever alguns aspectos clínicos e epidemiológicos observados em um surto de meningoencefalite determinado pelo BoHV-5 em um rebanho bovino leiteiro do estado do Paraná, Brasil. Neste surto, nove bezerros afetados apresentaram três formas distintas da doença, subjetivamente classificadas como hiperaguda, aguda e subaguda/crônica. Diferentemente da meningoencefalite herpética convencional, caracterizada principalmente por disfunções cerebrais multifocais progressivas, a infecção pelo BoHV-5 resultou em disfunção focal não-progressiva do tronco encefálico (síndrome pontobulbar) em um animal apresentando a meningoencefalite subaguda/crônica por BoHV-5. As avaliações de tecido do sistema nervoso de bezerros afetados, por meio do exame histológico e da técnica de multiplex- $P C R$, confirmaram a infecção pelo BoHV-5. Adicionalmente, a análise de amostras de líquor por meio da PCR permitiu o diagnóstico ante-mortem da infecção pelo BoHV5 , fato que possibilitou a implementação de várias medidas de controle para a doença durante o surto.

\section{REFERENCES}

Alfieri, A. A., Parazzi, M. E., Takiuchi, E., Médici, K. C., Alfieri, A. F. (2006), Frequency of group A rotavirus in diarrhoeic calves in Brazilian cattle herds, 1998-2002. Trop Anim Health Prod, 38, 521-526

Amude, A. M. (2008), Encefalomielite pelo vírus da cinomose canina: aspectos neuroclínicos e neuropatológicos e uso das técnicas de RT - PCR e imunoistoquímica no auxílio do diagnóstico Post Mortem. Thesis, Universidade Estadual de Londrina, Londrina, Brazil.

Ashbaugh, S. E., Thompson, K. E., Belknap, E. B., Schultheiss, P. C., Chowdhury, S., Collins, J. K. (1997), Specific detection of shedding and latency of Bovine herpesvirus 1 and 5 using a nested polymerase chain reaction. J Vet Diagn Invest, 9, 387-394

Belknap, E. B., Collins, J. K., Ayers, V. K., Schultheiss, P. C. (1994), Experimental infection of neonatal calves with neurovirulent bovine herpesvirus type 1.3. Vet Pathol, 31, 358-365

Carrillo, B. J., Ambrogí, A., Schudel, A. A., Vazquez, M., Dahme, E., Pospischil, A. (1983), Meningoencephalitis caused by IBR virus in calves in Argentina. Zentralbl Veterinarmed B, 30, 327-332

Cascio, K. E., Belknap, E. B., Schultheiss, P. C., Ames, A. D., Collins, J. K. (1999), Encephalitis induced by bovine herpesvirus 5 and protection by prior vaccination or infection with bovine herpesvirus $1 . J$ Vet Diagn Invest, 11, 134-139

Claus, M. P., Alfieri, A. F., Folgueras-Flatschart, A. V., Wosiacki, S. R., Médici, K. C., Alfieri, A. A. (2005), Rapid detection and differentiation of bovine herpesvirus 1 and 5 glycoprotein $\mathrm{C}$ gene in clinical specimens by multiplex-PCR. J Virol Methods, 128, $183-188$ 
Claus, M. P., Alfieri, A. F., Médici, K. C., Lunardi, M., Alfieri, A. A. (2007), Bovine herpesvirus 5 detection by virus isolation in cell culture and Multiplex-PCR in central nervous system from cattle with neurological disease in Brazilian herds. Braz $J$ Microbiol, 38, 485-490

Colodel, E. M., Nakazato, L., Weiblen, R., Mello, R. M., Silva, R. R. P., Souza, M. A., Filho, J. A. O., Caron, L. (2002), Meningoencefalite necrosante em bovinos causada por herpesvírus bovino no estado de Mato Grosso, Brasil. Cienc Rural, 32, 293-298

D’Offay, J. M., Mock, R. E., Robert, W., Fulton, D. V. M. (1993), Isolation and characterization of encephalitic bovine herpesvirus type 1 isolates from cattle in North America. Am J Vet Res, 54, 534-539

Del Médico Zajac, M. P., Puntel, M., Zamorano, P. I., Sadir, A. M., Romera, S. A. (2006), BHV-1 vaccine induces cross-protection against BHV-5 disease in cattle. Res Vet Sci, 81, 327-334

Elias, F., Schild, A. L., Riet-Correa, F. (2004), Meningoencefalite e encefalomalacia por Herpesvírus bovino-5: distribuição das lesões no sistema nervoso central de bovinos naturalmente infectados. Pesq Vet Bras, 24, 123-131

Ferreira, M. C., Médici, K. C., Alfieri, A. F., Alfieri, A. A. (2005), Desenvolvimento e avaliação de um ensaio imunoenzimático para o diagnóstico sorológico da infecção pelo herpesvírus bovino. Semina Ci Agr, 26, 363-372

Gomes, L. I., Rocha, M. A., Costa, E. A., Lobato, Z. I. P., Mendes, L. C. N., Borges, A. S., Leite, R. C., Barbosa-Stancioli, E. F. (2002), Detecção de herpesvírus bovino 5 (BoHV-5) em bovinos do sudeste brasileiro. Arq Bras Med Vet Zootec, 54, 217 220

Isernhagen, A. J. (2005), Meningoencefalite herpética em bezerros: evolução clínica e diagnóstico. MSc Dissertation, Universidade Estadual de Londrina, Londrina, Brazil

Johnston, L. A. Y., Simmons, G. C., McGavin, M. D. (1962), A viral meningoencephalitis in calves. Aust Vet J, 38, 207-215

Penny, C. D., Howie, F., Nettleton, P. F., Schock, A. (2002), Upper respiratory disease and encephalitis in neonatal beef calves caused by Bovine herpesvirus type 1. Vet Rec, 151, 89-91

Pérez, S. E., Bretschneider, M. R., Leunda, M. R., Osório, F. A., Flores, E. F., Odeón, A. C. (2002), Primary infection, latency, and reactivation of bovine herpesvirus type 5 in the bovine nervous system. Vet Pathol, 39, 437-444

Pérez, S. E., Vagnozzi, A., Sur, J. H., Odriozola, E., Campero, C. M., Odeón, A. C. (2003), Retrospective analysis of cases with a diagnosis of cerebrocortical necrosis and its relation with type 5 bovine herpesvirus. Rev Argent Microbiol, 35, 69-73
Riet-Correa, G., Duarte, M. D., Barbosa, J. D., Oliveira, M. C., Cerqueira, V. D., Brito, M. F., Riet-Correa, F. (2006), Meningoencefalite e polioencefalomalácia causadas por herpesvírus bovino-5 no estado do Pará. Pesq Vet Bras, 26, 44-46

Rissi, D. R., Oliveira, F. N., Rech, R. R., Pierezan, F., Lemos, R. A. A., Barros, C. S. L. (2006), Epidemiologia, sinais clínicos e distribuição das lesões encefálicas em bovinos afetados por meningoencefalite por herpesvírus bovino-5. Pesq Vet Bras, 26, 123-132

Rissi, D. R., Pierezan, F., Silva, M. S., Flores, E. F., Barros, C. S. L. (2008), Neurological disease in cattle in southern Brazil associated with bovine herpesvirus infection. J Vet Diagn Invest, 20, 346-349

Roels, S., Charlier, G., Letellier, C., Meyer, G., Schynts, F., Kerkhofs, P., Thiry, E., Vanopdenbosch, E. (2000), Natural case of bovine herpesvirus 1 meningoencephalitis in an adult cow. Vet Rec, 146, 586-588

Roizmann, B., Desrosiers, R. C., Fleckenstein, B., Lopez, C., Minson, A. C., Studdert, M. J. (1992), The family Herpesviridae: an update. Arch Virol, 123, 425-449

Salvador, S. C., Lemos, R. A. A., Riet-Correa, F., Roehe, P. M., Osório A. L. A. R. (1998), Meningoencefalite em bovinos causada por herpesvírus bovino-5 no Mato Grosso do Sul e São Paulo. Pesq Vet Bras, 18, 76-83

Sanches, A. W. D., Langohr, I. M., Stigger, A. L., Barros, C. S. L. (2000), Doenças do sistema nervoso central em bovinos no Sul do Brasil. Pesq Vet Bras, 20, 113-118

Spilki, F. R., Silva, T. C., Esteves, P. A., Teixeira, M. B., Batista, H. B. C. R., Chiminazzo, C., Driemeier, D., Franco, A. C., Roehe, P. M. (2006), Co-infections with bovine herpesvirus type 5 and bovine viral diarrhoea virus. Arq Bras Med Vet Zootec, 58, 699707

Summers, B. A., Cummings, J., De Lahunta, A. (1995), Veterinary neuropathology. Mosby, St. Louis, MO, p 527

Vogel, F. S. F., Caron, L., Flores, E. F., Weiblen, R., Winkelmann, E. R., Mayer, S. V., Bastos, R. G. (2003), Distribution of bovine herpesvirus type 5 in the central nervous systems of latently, experimentally infected calves. J Clin Microbiol, 41, 4512-4520

Vogel, F. S. F., Lima, M., Flores, E. F., Weiblen, R., Winkelmann, E. R., Mayer, S. V., Mazzutti, K. C., Arenhart, S. (2004), Replicação e excreção viral durante a infecção aguda e após a reativação da latência induzida por dexametasona em bezerros inoculados com os herpesvírus bovinos tipo 1 (BHV1) e 5 (BHV-5). Cienc Rural, 34, 1619-1621 


\section{PAGINA EM \\ BRANCO}

